\title{
Diallyl Disulfide and Helicobacter pylori
}

\author{
Sayed Alireza Mirsane, ${ }^{1, *}$ and Nasrin Oraei ${ }^{2}$ \\ ${ }^{1}$ Kashan University of Medical Sciences, Kashan, IR Iran \\ ${ }^{2}$ Lecturer of Education Office, Isfahan, IR Iran \\ "Corresponding author: Sayed Alireza Mirsane, Kashan University of Medical Sciences, Kashan, IR Iran. Tel: +98-3157232469, E-mail: alireza.seyed70@gmail.com
}

Received 2016 July 19; Revised 2016 August 05; Accepted 2016 August 05.

Keywords: Diallyl Disulfide, Infection, Helicobacter pylori

\section{Dear Editor,}

Helicobacter pylori (H. pylori) is a Gram-negative bacteria that colonize in the stomach of about half of the world population is one of the most common bacterial infections worldwide. Helicobacter pylori can activate the immune response of the host. Despite a vigorous humeral and cellular immune response, if untreated, this infection becomes chronic and persists all over life (1-3). Helicobacter pylori gastric infection is a major risk factor of gastric cardiac cancer and migraine exacerbation. Unfortunately, after long-term infection, $H$. pylori may develop gastric cancer in some patients (4-7). According to a hadith by Muhammad the prophet (may peace be upon him), garlic is a remedial foodstuff with biological properties. On the other hand, diallyl disulfide (DADS or 4, 5-dithia-1, 7-octadiene) is the main organosulfur derivative of garlic (8). And also, DADS is found in foods such as chive oil (9), Chinese leek oil (10), garlic oil (10) and Dracocephalum kotschyi $(11,12)$. Researchers demonstrated that DADS is a useful and effective material to improve and treat $H$. pylori infection (11, 13). A study by O'Gara et al. had similar results; they concluded that antimicrobial activities of the diallyl sulfides increased with the number of sulfur atoms. They also suggested that DADS acts against the gastric ulcer caused by H. pylori (14). Corzo-Martínez showed that DADS also acts against the gastric ulcer caused by H. pylori (15). Researches indicated that $H$. pylori infection can motivate cells to synthesize and secrete 5-hydroxytryptamine (HT); and following that stimulate the cell to secrete 5-HT and create central nervous system (CNS) disorder by the brain-gut axis, which can increase the period and intensity of migraine headaches. Relieving $H$. pylori infection has beneficial results for migraine betterment because these interventions can reduce the period and intensity of this disorder $(7,16)$. Therefore, DADS can be a vulnerary and remedial factor for $H$. pylori infection and migraine. Based on the present study, it can be concluded that DADS has helpful and good efficiency in the treatment and control of $H$. pylori infection. Thus it can be as an anti-migraine, anti-gastric car- diac cancer and anti-gastric cancer; it can also be stated that DADS is a therapeutic substance for the other complications result from $H$. pylori infection. Finally, it is recommended to conduct more studies to find the new benefits of DADS.

\section{References}

1. Peek RM, Blaser MJ. Helicobacter pylori and gastrointestinal tract adenocarcinomas. Nat Rev Cancer. 2002;2(1):28-37. doi: 10.1038/nrc703. [PubMed: 11902583].

2. Romano M, Ricci V, Zarrilli R. Mechanisms of disease: Helicobacter pylori-related gastric carcinogenesis-implications for chemoprevention. Nat Clin Pract Gastroenterol Hepatol. 2006;3(11):622-32. doi: 10.1038/ncpgasthep0634. [PubMed: 17068500].

3. Salama NR, Hartung ML, Muller A. Life in the human stomach: persistence strategies of the bacterial pathogen Helicobacter pylori. Nat Rev Microbiol. 2013;11(6):385-99. doi: 10.1038/nrmicro3016. [PubMed: 23652324].

4. Goldblum JR, Richter JE, Vaezi M, Falk GW, Rice TW, Peek RM. Helicobacter pylori infection, not gastroesophageal reflux, is the major cause of inflammation and intestinal metaplasia of gastric cardiac mucosa. Am J Gastroenterol. 2002;97(2):302-11. doi: 10.1111/j.15720241.2002.05462.x. [PubMed: 11866266].

5. Kamangar F, Qiao YL, Blaser MJ, Sun XD, Katki H, Fan JH, et al. Helicobacter pylori and oesophageal and gastric cancers in a prospective study in China. Br J Cancer. 2007;96(1):172-6. doi: 10.1038/sj.bjc.6603517. [PubMed: 17179990].

6. Kamangar F, Dawsey SM, Blaser MJ, Perez-Perez GI, Pietinen P, Newschaffer CJ, et al. Opposing risks of gastric cardia and noncardia gastric adenocarcinomas associated with Helicobacter pylori seropositivity. J Natl Cancer Inst. 2006;98(20):1445-52. doi: 10.1093/jnci/djj393. [PubMed: 17047193].

7. Mirsane SA, Shafagh S. Effects of Helicobacter pylori Infection and Western Diet on Migraine. Gene Cell Tissue. 2016:39212.

8. Di CX, Han L, Zhang H, Xu S, Mao AH, Sun C, et al. Diallyl disulfide attenuated carbon ion irradiation-induced apoptosis in mouse testis through changing the ratio of Tap73/DeltaNp73 via mitochondrial pathway. Sci Rep. 2015;5:16020. doi: 10.1038/srep16020. [PubMed: 26526304].

9. Rattanachaikunsopon P, Phumkhachorn P. Diallyl sulfide content and antimicrobial activity against food-borne pathogenic bacteria of chives (Allium schoenoprasum). Biosci Biotechnol Biochem. 2008;72(11):2987-91. doi: 10.1271/bbb.80482. [PubMed: 18997412].

10. Tsao SM, Yin MC. In-vitro antimicrobial activity of four diallyl sulphides occurring naturally in garlic and Chinese leek oils. J Med Microbiol. 2001;50(7):646-9. doi: 10.1099/0022-1317-50-7-646. [PubMed: 11444776]. 
11. Mirsane SA, Mirsane SM. The effects of hydroalcoholic extract of dracocephalum kotschyi on blood glucose and lipid profile in diabetic rats. J Fasa Univ Med Sci. 2016;6(1):129-30.

12. Eskandari M, Mohammadi J, Delaviz H, Hossieni E. The effects of hydroalcoholic extract of dracocephalum kotschyi on blood glucose and lipid profile in diabetic rats. J Fasa Univ Med Sci. 2016;5(4):526-33.

13. Avato P, Tursi F, Vitali C, Miccolis V, Candido V. Allylsulfide constituents of garlic volatile oil as antimicrobial agents. Phytomedicine. Int J Phytotherapy Phytopharmacol. 2000;7(3):239-43.
14. O'Gara EA, Hill DJ, Maslin DJ. Activities of garlic oil, garlic powder, and their diallyl constituents against Helicobacter pylori. Appl Environ $\mathrm{Mi}$ crobiol. 2000;66(5):2269-73. [PubMed:10788416]

15. Corzo-Martínez M, Corzo N, Villamiel M. Biological properties of onions and garlic. Trends Food Sci Technol. 2007;18(12):609-25.

16. Seyyedmajidi M, Banikarim SA, Ardalan A, Hozhabrossadati SH, Vafaeimanesh Norouzi A. Helicobacter pylori and Migraine: Is Eradication of Helicobacter pylori Effective in Relief of Migraine Headache? J. Caspian J Neurol Sci. 2016;2(4):29-35. 